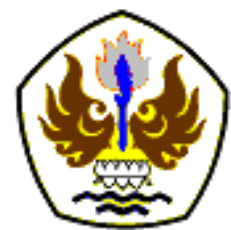

INFOMATEK

Volume 22 Nomor 2 Desember 2020

\title{
PENENTUAN KLASIFIKASI BEBAN KERJA BARU BERDASARKAN PREDIKSI KADAR OKSIGEN DALAM DARAH DENGAN MEMPERTIMBANGKAN DENYUT JANTUNG, TEMPERATUR TUBUH DAN KONSUMSI OKSIGEN PADA PEKERJA JASA KULI ANGKUT
}

\author{
Hermita Dyah Puspita ${ }^{*}$, Gianti Puspawardhani \\ Jurusan Teknik Industri \\ Fakultas Teknologi Manufaktur, Universitas Jenderal Achmad Yani
}

\begin{abstract}
Abstrak: Aktifitas pengangkutan barang merupakan kegiatan yang tidak bisa dilepaskan dari sistem pemindahan barang di pasar tradisional dan dapat mempengaruhi beban kerja fisik operator/kuli angkut. Beban kerja fisik operator/kuli angkut di pasar dipengaruhi oleh banyak faktor diantaranya yaitu :berat dari benda/bahan yang dipindahkan, posisi pembebanan dengan mengacu pada titik berat tubuh, frekuensi pemindahan dan durasi total waktu dalam proses pemindahan bahan. Dalam praktiknya, beban kerja fisik pekerja yang berat ditambah dengan postur tubuh yang monoton menimbulkan kinerja yang rendah dan dapat mengakibatkan penyakit akibat kerja (PAK). Kinerja faal tubuh dan kenyamanan pekerja pada manual material handling (MMH) sudah terbukti sangat menunjang tingkat produktivitas pekerja. Proses metabolisme yang terjadi dalam tubuh manusia sebagai penghasil energi pada saat melakukan kerja fisik merupakan phase yang penting. Panas dan energi yang dihasilkan dari proses metabolisme dibutuhkan pada saat kerja fisik (mekanis) melalui system otot manusia. Energi dalam fisiologi kerja dapat diukur secara langsung dengan mengukur konsumsi oksigen yang dihirup oleh tubuh. Pengukuran energi yang dikeluarkan pada saat kerja fisik dapat diukur dengan cara lain yaitu dengan membandingkan konsumsi oksigen dengan laju detak jantung. Tujuan penelitian ini adalah menghasilkan persamaan prediksi kadar oksigen dalam darah dengan mempertimbangkan tiga variabel independent, yaitu : persentase HRR (\%CVL), konsumsi oksigen, dan temperatur tubuh pekerja. Dari hasil prediksi dibuat klasifikasi baru beban fisik kerja berdasarkan kadar oksigen dalam darah.
\end{abstract}

Kata kunci: Klasifikasi Beban Kerja Fisik ,HRR ,Temperatur, Konsumsi Oksigen, Kadar Oksigen dalam darah

\section{PENDAHULUAN}

Kerja fisik adalah kegiatan yang memberi pembebanan bagi tubuh dan dapat mengakibatkan perubahan pada fungsi organorgan tubuh. Pada saat kerja fisik terjadi mekanisme penyesuaian dari organ tubuh,

*) hermitadp@yahoo.com.sg

Pertama diterima: 3 Juli 2020

Direvisi: 11 November 2020

Disetujui untuk publikasi: 17 November 2020 seperti konsumsi oksigen, kecepatan denyut jantung, perubahan kadar kimia dalam darah dan perubahan temperature tubuh, dimana salah satu faktor yang mempengaruhi adalah berat ringannya beban yang diterima.

Menurut Al Faritsy \& Nugroho (2017)[1] denyut jantung dipengaruhi oleh temperatur lingkungan, berat badan dan tingkat beban 
kerja. Sedangkan alokasi waktu istirahat dapat menurunkan denyut nadi pekerja dalam bekerja untuk mengurangi kelelahan kerja (Salsia [2]).

Dalam melakukan pekerjaan, kemampuan fisik digambarkan sebagai aktivitas dari otot-otot tubuh yang bergantian berkontraksi. Pada saat otot mengencang dalam waktu yang lama akan berakibat pada terganggunya aliran darah sehingga suplai darah dan glukosa terhambat. Hal tersebut mengakibatkan metabolisme tidak bisa segera terbuang. Kondisi seperti itu akan mengakibatkan rasa lelah dan sakit pada otot (Wignjosoebroto [3]). Kelelahan otot diakibatkan oleh adanya sisasisa zat metabolisme. Istilah metabolisme digunakan untuk menggambarkan seluruh proses pengeluaran energi. Pengeluaran energi berhubungan erat dengan konsumsi energi dan denyut jantung. Pengklasifikasian pekerjaan menurut jenisnya berdasarkan evaluasi nilai absolute kebutuhan energi setiap individu dapat dilihat pada Tabel 1.

Tabel 1 Klasifikasi jenis pekerjaan berdasarkan $\mathrm{VO}_{2}$, denyut jantung dan pengeluaran energi (Kromer dalam Soleman [4])

\begin{tabular}{|c|c|c|c|c|}
\hline \multirow[b]{2}{*}{ Kriteria Beban Kerja } & \multicolumn{2}{|c|}{ Total Pengeluaran Energi } & \multirow{2}{*}{$\begin{array}{c}\text { Denyut } \\
\text { Jantung } \\
\text { (denyut/menit) }\end{array}$} & \multirow[b]{2}{*}{$\mathrm{VO}_{2}(L /$ menit $)$} \\
\hline & Kj/Menit & Kkal/menit & & \\
\hline Ringan & $10-20$ & $<2.5$ & $\leq 90$ & $<0.5$ \\
\hline Sedang & $20-30$ & $2.5-5.0$ & $90-110$ & $0.5-1.0$ \\
\hline Berat & $30-40$ & $5.0-7.5$ & $110-130$ & $1.0-1.5$ \\
\hline Sangat Berat & $40-50$ & $7.5-10$ & $130-150$ & $1.5-2.0$ \\
\hline Ekstrem Berat & $50-60$ & $>10$ & $150-170$ & $>2.0$ \\
\hline
\end{tabular}

Tabel 1 menunjukkan ukuran denyut jantung digunakan untuk menganalisa dan mengevaluasi beban kerja. Semakin berat kerja fisik seseorang maka semakin berat juga kerja jantung yang diindikasikan dengan adanya kenaikan nilai denyut jantung.

Pekerja kuli angkut merupakan pekerjaan yang aktifitas kerjanya menggunakan fisik. Pekerja kuli angkut masih banyak ditemukan di pasar-pasar tradisional, terminal dan stasiun kereta api. Aktifitas mengangkat dan mengangkut beban yang dilakukan oleh pekerja kuli angkut dipasar tradisional yaitu dengan cara memanggul dengan menggunakan bagian tubuh. Aktifitas kuli angkut tersebut dapat membahayakan kondisi tubuh karena beban yang diangkatnya melebihi batas ditambah postur kerja yang tidak sesuai dengan prinsip biomekanika dalam ergonomi . Peraturan Kepmenakertranskop No 1 Tahun 1978 telah mengatur beban maksimum yang diperkenankan agar tidak menimbulkan kecelakaan seperti ditunjukkan dalam Tabel 2. 
Tabel 2. Beban kerja Menurut jenis kelamin (Kepmenakertranskop [5])

\begin{tabular}{|c|c|c|c|c|}
\hline \multirow{2}{*}{ Angkat-angkut } & \multicolumn{2}{|c|}{ Pekerja Dewasa ( $>\mathbf{1 7}$ Tahun) } & \multicolumn{2}{c|}{ Pekerja Muda $(<\mathbf{1 7}$ Tahun) } \\
\cline { 2 - 5 } & Laki-laki (Kg) & Wanita (Kg) & Laki-laki (Kg) & Wanita (Kg) \\
\hline Mengangkat Sesekali & 40 & 15 & 15 & $10-12$ \\
\hline Terus Menerus & $15-18$ & 10 & $10-15$ & $6-9$ \\
\hline
\end{tabular}

Sumber : No. Per-01/MEN/1978

Dalam kondisi oksigen yang tidak tercukupi dan akan mengakibatkan meningkatnya kandungan asam laktat, sedangkan asam laktat merupakan manifestasi dari kelelahan, maka berat beban yang melebihi batas kemampuan fisik tidak dapat dilaksanakan (Nurmianto [6]). Ergonomi juga mempelajari tentang beban kerja fisik dan jantung dikaitkan dengan kemampuan dan keterbatasan manusia secara fisik dan mental yang dapat meningkatkan kelelahan kerja. Faktor lain yang dapat meningkatkan kelelahan kerja adalah antropometri, karena ukuran tubuh menentukan pola kemampuan fisik tenaga kerja.

Mutia (2014)[7] melakukan pengukuran beban kerja fisiologis dengan menghitung kebutuhan kalori, persentase CVL dan konsumsi masingmasing operator dengan melakukan pengukuran denyut nadi dan suhu operator menggunakan metode beban kardiovascular (\%CVL). Sedangkan Silalahi (2018)[8] meneliti beban kerja fisik berdasarkan nilai persentase HRR dan konsumsi oksigen (liter/menit). Benedikta (2016)[9] membuat pengembangan persamaan prediksi konsumsi Oksigen pada mahasiswa pekerja industri dengan Variabel dependent-nya adalah Konsumsi $\left(\mathrm{VO}_{2}\right) \mathrm{Max}$ dan variabel independent : Umur, Jenis Pekerjaan, Berat Badan, Riwayat Kesehatan dan Lamanya Kerja.

Salah satu elemen yang terpenting bagi tubuh manusia adalah oksigen, karena otak manusia memanfaatkan hampir $20 \%$ oksigen. angka normal kadar oksigen dalam tubuh manusia harus berkisar antara $85-100 \%$. Alat yang dapat melakukan pengukuran kadar oksigen pada tubuh yaitu pulse oximetry. Jika nilai pengukurun dibawah $85 \%$ maka menandakan bahwa jaringan tubuh tidak mendapatkan oksigen yang cukup dan akan menimbulkan dampak buruk bagi tubuh seperti kelelahan akibat kerja, kesulitan bernafas, nyeri otot, gangguan mata, tubuh menjadi pucat, hingga serangan jantung, serta akan berdampak negatif pada fungsi otak.

Berdasarkan permasalahan di atas, maka tujuan dalam penelitian ini adalah menghasilkan persamaan prediksi kadar oksigen dalam darah dengan mempertimbangkan tiga variabel independent, yaitu: persentase HRR (\%CVL), konsumsi oksigen, dan temperatur tubuh pekerja. Dari hasil prediksi tersebut akan dibuat klasifikasi 
baru beban fisik kerja berdasarkan kadar oksigen dalam darah.

\section{METODOLOGI}

Metodologi penelitian menggambarkan langkah-langkah yang akan ditempuh dalam melakukan penelitian. Langkah-langkah ini ditunjukkan untuk memperjelas dan menuntun proses penelitian agar tujuan yang diinginkan dapat tercapai dengan baik. Skema metodologi penelitian dapat dilihat pada Gambar 1.

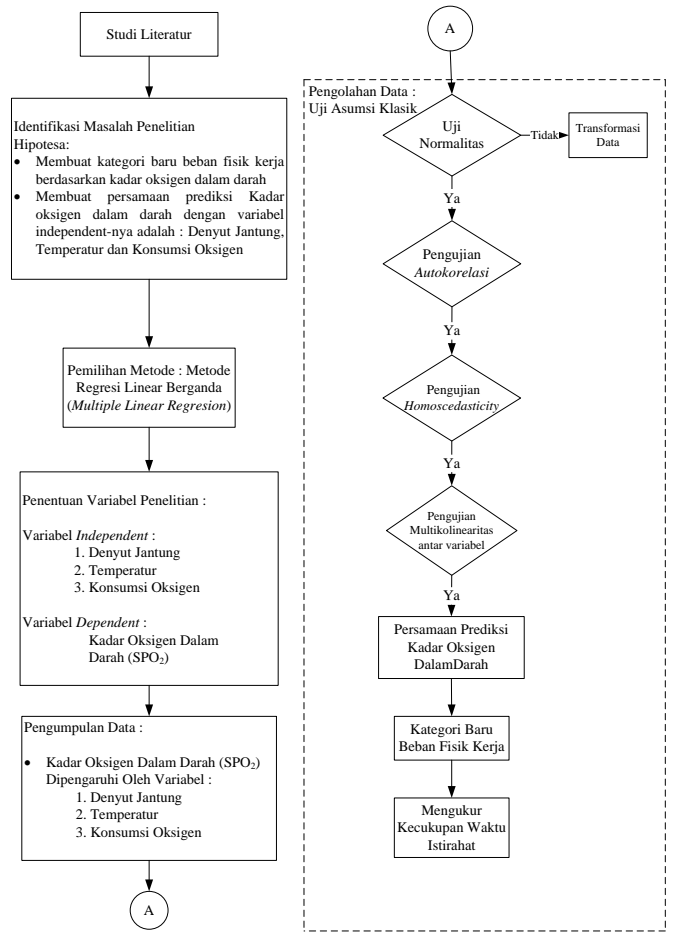

Gambar 1.

Skema Metodologi Penelitian

Sumber data pada penelitian ini diperoleh dari hasil wawancara dan penyebaran kuisioner terbuka kepada 35 responden pekerja jasa kuli angkut yang ada di kota Bandung. Total responden berjumlah 35 orang responden dengan rincian 25 responden dengan jenis kelamin laki-laki dan 10 responden dengan jenis kelamin perempuan.

\section{ANALISIS DAN PEMBAHASAN}

\subsection{Karakteristik Responden}

Karakteristik responden dalam penelitian ini yaitu meliputi usia, jenis kelamin body mass index (BMI), berat beban, denyut jantung sebelum dan sesudah, kadar oksigen dalam darah sebelum dan sesudah dan jam kerja dari pekerja jasa kuli angkut yang ada di kota Bandung adalah sebagai berikut:

Tabel 3. Karakteristik Responden

\begin{tabular}{|c|c|c|c|}
\hline No & $\begin{array}{c}\text { Karakteristik } \\
\text { Responden }\end{array}$ & $\begin{array}{l}\text { Frekuensi } \\
\text { (F) }\end{array}$ & $\begin{array}{c}\text { Persentase } \\
(\%)\end{array}$ \\
\hline \multirow{5}{*}{1} & \multicolumn{3}{|c|}{ Usia } \\
\hline & $\begin{array}{c}\text { Dewasa Awal } \\
(25-35)\end{array}$ & 15 & 42,86 \\
\hline & $\begin{array}{c}\text { Dewasa Akhir } \\
(36-45)\end{array}$ & 13 & 37,14 \\
\hline & $\begin{array}{c}\text { Lansia Awal } \\
(46-55)\end{array}$ & 7 & 20 \\
\hline & Total & 35 & 100 \\
\hline \multirow{4}{*}{2} & \multicolumn{3}{|c|}{ Jenis Kelamin } \\
\hline & Laki-laki & 25 & 71,43 \\
\hline & Perempuan & 10 & 28,57 \\
\hline & Total & 35 & 100 \\
\hline \multirow{5}{*}{3} & \multicolumn{3}{|c|}{ BMI } \\
\hline & $\begin{array}{l}\text { Kekurangan } \\
\text { Berat Badan }\end{array}$ & 0 & 0 \\
\hline & Normal & 24 & 68,57 \\
\hline & $\begin{array}{c}\text { Kelebihan } \\
\text { Berat Badan }\end{array}$ & 11 & 31,43 \\
\hline & Total & 35 & 100 \\
\hline \multirow{4}{*}{4} & \multicolumn{3}{|c|}{ Berat Beban } \\
\hline & $<20 \mathrm{~kg}$ & 3 & 8,57 \\
\hline & $>20 \mathrm{~kg}$ & 32 & 91,43 \\
\hline & Total & 35 & 100 \\
\hline \multirow{4}{*}{5} & \multicolumn{3}{|c|}{ Denyut Jantung (Sebelum) } \\
\hline & Ringan $(\leq 90)$ & 22 & 62,86 \\
\hline & $\begin{array}{c}\text { Sedang (90- } \\
110)\end{array}$ & 13 & 37,14 \\
\hline & $\begin{array}{c}\text { Berat (110- } \\
130) \\
\end{array}$ & 0 & 0 \\
\hline
\end{tabular}




\begin{tabular}{|c|c|c|c|}
\hline No & $\begin{array}{l}\text { Karakteristik } \\
\text { Responden }\end{array}$ & $\begin{array}{l}\text { Frekuensi } \\
\text { (F) }\end{array}$ & $\begin{array}{c}\text { Persentase } \\
\text { (\%) }\end{array}$ \\
\hline & $\begin{array}{c}\text { Sangat Berat } \\
(130-150)\end{array}$ & 0 & 0 \\
\hline & $\begin{array}{c}\text { Ekstrem Berat } \\
(150-170)\end{array}$ & 0 & 0 \\
\hline & Total & 35 & 100 \\
\hline \multirow{7}{*}{6} & \multicolumn{3}{|c|}{ Denyut Jantung (Sesudah ) } \\
\hline & Ringan $(\leq 90)$ & 0 & 0 \\
\hline & $\begin{array}{c}\text { Sedang (90- } \\
110)\end{array}$ & 3 & 8,57 \\
\hline & $\begin{array}{c}\text { Berat (110- } \\
130)\end{array}$ & 24 & 68,57 \\
\hline & $\begin{array}{c}\text { Sangat Berat } \\
(130-150)\end{array}$ & 7 & 20 \\
\hline & $\begin{array}{c}\text { Ekstrem Berat } \\
(150-170)\end{array}$ & 1 & 2,86 \\
\hline & Total & 35 & \\
\hline \multirow{4}{*}{7} & \multicolumn{3}{|c|}{$\mathrm{SPO}^{2}$ (Sebelum) } \\
\hline & $<85 \%$ & 0 & 0 \\
\hline & $>85 \%$ & 35 & 100 \\
\hline & Total & 35 & 100 \\
\hline \multirow{4}{*}{8} & \multicolumn{3}{|c|}{ SPO $^{2}$ (Sesudah) } \\
\hline & $<85 \%$ & 23 & 65,71 \\
\hline & $>85 \%$ & 12 & 34,29 \\
\hline & Total & 35 & 100 \\
\hline \multirow{4}{*}{9} & \multicolumn{3}{|c|}{ Jam Kerja } \\
\hline & $<7$ Jam & 4 & 11,43 \\
\hline & $>7$ Jam & 31 & 88,57 \\
\hline & Total & 35 & 100 \\
\hline
\end{tabular}

Jumlah responden yang digunakan dalam penelitian ini sebanyak 35 orang, terdiri dari laki-laki $71,43 \%$ dan perempuan $28,57 \%$.

Rentang usia pekerja jasa kuli angkut dalam penelitian dari 25-55 tahun. Dari ketiga kategori usia pekerja jasa kuli angkut, persentase terbesar berada pada kategori usia dewasa awal 25-35 tahun. Hal tersebut dikarenakan Indonesia termasuk ke dalam negara berkembang yang masih memiliki tenaga kerja dengan keterampilan dan tingkat pendidikan yang rendah serta memiliki konsekuensi beban kerja yang mengarah bekerja secara fisik. Kekuatan otot maksimal terjadi pada umur 20-29 tahun (Tarwaka, [10]). Dengan semakin bertambahnya usia kekuatan otot akan mngalami penurunan dan juga akan mengalami proses degenerasi organ yang akan menyebabkan penurunan kemampuan organ tersebut (Grandjean [11]).

Data tinggi badan dan berat badan digunakan untuk mencari Body Mass Index (BMI) yaitu untuk mengetahui kenormalan berat badan seseorang. Body Mass Index pekerja jasa kuli angkut untuk kategori kekurangan berat badan $0 \%$, kategori normal $68,57 \%$ dan kategori kelebihan berat badan $31,43 \%$.

Berat beban yang diangkat dan diangkut oleh pekerja jasa kuli angkut yang ada di kota Bandung, dalam sekali angkat-angkut berat beban berkisar antara 10 sampai dengan 25 $\mathrm{kg}$. Kategori mengangkat beban kurang dari $20 \mathrm{~kg} \mathrm{8,57 \%}$ dan kategori mengangkat beban lebih dari $20 \mathrm{~kg} \mathrm{91,43 \% .} \mathrm{Kategori} \mathrm{mengangkat}$ beban lebih dari $20 \mathrm{~kg}$ lebih dominan. Hal ini dapat membahayakan kondisi tubuh para pekerja jasa kuli angkut dan akan berakibat berbagai keluhan penyakit khususnya pada bagian tulang belakang.

Pengambilan data dilakukan dengan pengukuran denyut jantung dan kadar oksigen dalam darah sebelum dan sesudah bekerja, denyut jantung digunakan untuk mengetahui kategori jenis pekerjaan dan kadar oksigen dalam darah digunakan untuk mengetahui konsentrasi seseorang. 
Denyut jantung pekerja jasa kuli angkut sebelum bekerja, sebanyak $22(62,86 \%)$ orang termasuk kedalam kategori ringan, sebanyak 13 orang $(37,14 \%)$ orang termasuk kedalam kategori sedang, sebanyak 0 orang $(0 \%)$ orang termasuk kedalam kategori berat, kategori sangat berat dan kategori ekstrem berat. Hasil persentase paling besar termasuk kedalam kategori pekerjaan yang ringan karena disini responden masih dalam keadaan normal dan belum melakukan aktivitas yang berat. Denyut jantung sesudah bekerja, sebanyak 0 orang $(0 \%)$ termasuk kedalam kategori ringan, sebanyak 3 orang (8,57\%) termasuk kedalam kategori sedang, sebanyak 24 orang $(68,57 \%)$ termasuk kedalam kategori berat, sebanyak 7 orang (20\%) termasuk kedalam kategori sangat berat dan sebanyak 1 orang $(2,86 \%$.) termasuk kedalam kategori ekstrem berat.

Kadar oksigen dalam darah sebelum bekerja sebanyak 35 orang (lebih dari 85\%). Hal tersebut menunjukan bahwa konsentrasi pekerja sebelum bekerja sangat bagus dan mempunyai tingkat konsentrasi yang baik. Sedangkan kadar oksigen dalam darah sesudah bekerja sebanyak 23 orang $(65,71 \%)$ kurang dari $85 \%$ dan sebanyak 12 orang $(34,29 \%)$ lebih dari $85 \%$, hasil dari kadar oksigen dalam darah terebut menunjukan bahwa konsentrasi sesudah bekerja tersebut tidak sebaik sebelum bekerja.
Jam kerja pekerja jasa kuli angkut tidak ada standar tetapnya tetapi setelah melakukan observasi di lapangan dengan cara wawancara menggunakan kuisioner jam kerja kuli angkut kurang dari 7 jam sebanyak 4 orang dan jam kerja yang lebih dari 7 jam sebanyak 31 orang.

\subsection{Pengujian Asumsi Klasik}

1. Uji Asumsi Normalitas Untuk Variabel Dependent Kadar $\mathrm{O}_{2}$ dalam darah

Pengujian distribusi normal dilakukan dengan bantuan SPSS Versi 20. Hasil pengujian tersebut ditunjukkan pada tabel 4 dimana data Kadar $\mathrm{O}_{2}$ dalam darah berdistribusi normal dengan Asymp. Signifikansi sebesar 0,2 > 0.05( $\alpha$ ). Dengan demikian dapat disimpulkan data kadar $\mathrm{O}_{2}$ dalam darah berdistribusi normal terpenuhi.

Tabel 4. Uji Kolmogorov-Smirnov

\begin{tabular}{|c|c|c|}
\hline & & $\begin{array}{c}\text { Kadar } \mathrm{O}_{2} \\
\text { Dalam Darah }\end{array}$ \\
\hline $\mathrm{N}$ & & 35 \\
\hline Normal & Mean & 83.7143 \\
\hline Parameters $^{\mathrm{a}, \mathrm{b}}$ & Std. Deviation & 8.52530 \\
\hline Most Extreme & Absolute & .103 \\
\hline Differences & Positive & .097 \\
\hline & Negative & -.103 \\
\hline Test Statistic & & .103 \\
\hline Asymp. Sig. (2 & tailed) & $.200^{\mathrm{c}, \mathrm{d}}$ \\
\hline a. Test distribu & ion is Normal. & \\
\hline b. Calculated & om data. & \\
\hline c. Lilliefors Sig & ificance Corre & \\
\hline d. This is a lo & bound of th & hificance \\
\hline
\end{tabular}

2. Uji Asumsi Autokorelasi

Uji asumsi autokorelasi untuk mendeteksi gejala autokorelasi yaitu dengan 
menggunakan uji Durbin-Watson (DW). Berdasarkan jumlah sampel (n) yang digunakan, maka diperoleh nilai DW. Jumlah sampel dalam penelitian 35 responden dengan jumlah variabel independen yang berpengaruh ( $k$ ) yaitu 3 (denyut jantung, suhu dan konsumsi oksigen). Berikut ini adalah uji autokorelasinya:

Tabel 5. Uji Autokorelasi

\begin{tabular}{|l|c|c|c|c|r|}
\hline Model & $\mathbf{R}$ & $\mathbf{R}$ Square & $\begin{array}{c}\text { Adjusted R } \\
\text { Square }\end{array}$ & $\begin{array}{c}\text { Std. Error of the } \\
\text { Estimate }\end{array}$ & Durbin-Watson \\
\hline 1 & $.612^{\mathrm{a}}$ & .374 & .313 & 7.06441 & 1.416 \\
\hline \multicolumn{2}{l}{ a. Predictors: (Constant), Denyut Jantung, Suhu, Konsumsi O2 } \\
\hline
\end{tabular}

Tidak terjadi Autokorelasi jika nilai DW berada diatara -2 dan 2. Dari tabel 5 terlihat bahwa nilai Durbin Watson (DW)-nya adalah 1.416. Dengan demikian dapat disimpulkan tidak terjadi Autokorelasi.

\section{Uji Asumsi Homocedasticity}

Suatu model regresi dikatakan baik jika tidak terjadi heteroskesdastisitas atau dengan kata lain adalah homokedastisitas.

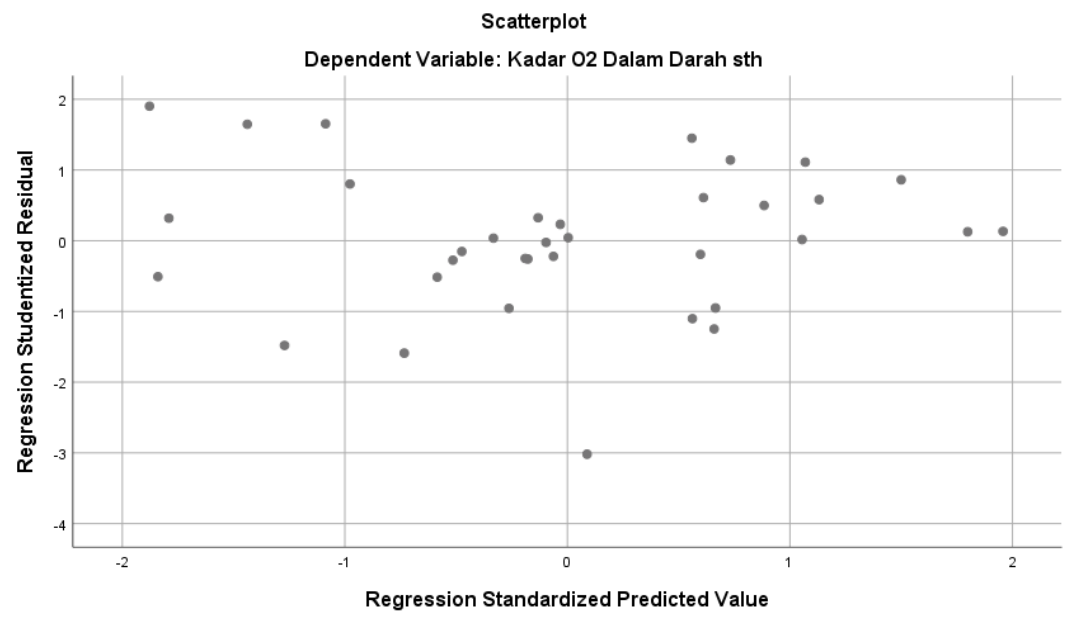

Gambar 2.

Uji Homocedasticity

Pada Gambar 2 terlihat bahwa penyebaran residual data penelitian adalah tidak teratur. Hal tersebut dapat dilihat pada scattterplot yang terpencar dan tidak membentuk pola tertentu. Dengan demikian dapat disimpulkan bahwa tidak terjadi gejala heteroskedastisitas.
4. Uji Asumsi Multikolinearitas

Pada pengujian ini variabel independen harus dinyatakan terbebas dari gejala multikolinearitas. Jika terdapat gejala korelasi antar variabel independen, maka hal tersebut menunjukkan adanya gejala multikolinearitas. Pada saat nilai VIF (Variance Inflation Factor) tidak 
melebihi 10 dan nilai toleransi $>0.10$ pada rendah menunjukan kolinearitas yang rendah model regresi, maka hal tersbut menunjukkan antar variabel.

tidak ada multikolinearitas. Nilai VIF yang

Tabel 6. Uji Multikolinieritas

\begin{tabular}{|c|c|c|c|c|c|c|c|c|}
\hline \multirow{2}{*}{\multicolumn{2}{|c|}{ Model }} & \multicolumn{2}{|c|}{$\begin{array}{l}\text { Unstandardized } \\
\text { Coefficients }\end{array}$} & \multirow{2}{*}{$\begin{array}{c}\begin{array}{c}\text { Standardized } \\
\text { Coefficients }\end{array} \\
\text { Beta } \\
\end{array}$} & \multirow[b]{2}{*}{$\mathbf{t}$} & \multirow[b]{2}{*}{ Sig. } & \multicolumn{2}{|c|}{$\begin{array}{l}\text { Collinearity } \\
\text { Statistics }\end{array}$} \\
\hline & & B & Std. Error & & & & Tolerance & VIF \\
\hline \multirow[t]{4}{*}{1} & (Constant) & 193.344 & 45.499 & & 4.249 & .000 & & \\
\hline & Suhu & -1.071 & 1.164 & -.131 & -.921 & .364 & .999 & 1.001 \\
\hline & Konsumsi O2 & 12.955 & 9.286 & .309 & 1.395 & .173 & .413 & 2.424 \\
\hline & $\begin{array}{l}\text { Denyut Jantung } \\
\text { sesdh }\end{array}$ & -.677 & .186 & -.803 & -3.628 & .001 & .413 & 2.423 \\
\hline
\end{tabular}

a. Dependent Variable: Kadar O2 Dalam Darah

Hasil dari tabel 6 menunjukkan bahwa nilai toleransi dari setiap variabel independent lebih dari 0.10 dan nilai Nilai VIF tidak melebihi 10, sehingga dapat disimpulkan tidak terjadi multikolinearitas.

Tabel 7. Collinearity Diagnostics ${ }^{a}$

\begin{tabular}{|c|c|c|c|c|c|c|c|}
\hline \multirow[b]{2}{*}{ Model } & \multirow[b]{2}{*}{ Dimension } & \multirow[b]{2}{*}{ Eigenvalue } & \multirow[b]{2}{*}{$\begin{array}{c}\text { Condition } \\
\text { Index }\end{array}$} & \multicolumn{4}{|c|}{ Variance Proportions } \\
\hline & & & & (Constant) & Suhu & Konsumsi 02 & $\begin{array}{l}\text { Denyut } \\
\text { Jantung } \\
\text { sesdh }\end{array}$ \\
\hline \multirow[t]{4}{*}{1} & 1 & 3.976 & 1.000 & .00 & .00 & .00 & .00 \\
\hline & 2 & .022 & 13.438 & .01 & .01 & .41 & .00 \\
\hline & 3 & .002 & 44.180 & .01 & .05 & .56 & .93 \\
\hline & 4 & .000 & 101.752 & .98 & .94 & .03 & .07 \\
\hline
\end{tabular}

a. Dependent Variable: Kadar O2 Dalam Darah

5. Uji Keterandalan Model Regresi (Uji F)

Untuk mengidentifikasi model regresi linear yang diestimasi layak atau tidak digunakan Uji F. Jika model dinyatakan layak maka model yang diestimasi layak digunakan untuk menjelaskan pengaruh variabel-variabel independent terhadap variabel dependent.
Tabel 8 menunjukkan uji model regresi. Nilai signifikansi pada model regresi pada tabel 8 menunjukkan nilai 0,002 yang lebih kecil dari $\alpha$ sebesar 0.05, sehingga dapat ditarik kesimpulan bahwa model regresi linear yang diestimasi layak digunakan.

Tabel 8. Uji Model Regresi

\begin{tabular}{|l|l|r|r|r|r|r|}
\hline \multicolumn{2}{|l|}{ Model } & Sum of Squares & \multicolumn{1}{c|}{ df } & Mean Square & \multicolumn{1}{c|}{ F } & Sig. \\
\hline \multirow{4}{*}{1} & Regression & 924.059 & 3 & 308.020 & 6.172 & $.002^{\mathrm{D}}$ \\
\cline { 2 - 8 } & Residual & 1547.084 & 31 & 49.906 & & \\
\cline { 2 - 8 } & Total & 2471.143 & 34 & & & \\
\hline
\end{tabular}

a. Dependent Variable: Kadar O2 Dalam Darah

b. Predictors: (Constant), Denyut Jantung, Suhu, Konsumsi $\mathrm{O}_{2}$ 


\subsection{Interpretasi Model Regresi Linear}

\section{Berganda}

Tanda dalam koefisien regresi menunjukan arah hubungan. Pengaruh yang searah antara variabel bebas dan variabel terikat ditunjukkan dengan tanda positif sedangkan tanda negatif menunjukan pengaruh yang berlawanan arah. Sedangkan besaran koefisen menjelaskan nominal slope dari persamaan regresi. Berikut ini adalah persamaan prediksi untuk kadar oksigen dalam darah:

$\hat{y}=193,344-0,677 X_{1}-1,071 X_{2}+12,955 X_{3}$

Keterangan:

Denyut Jantung ( X1)

Suhu ( X2)

Konsumsi $\mathrm{O}_{2}(\mathrm{X} 3)$

Dari persamaan prediksi kadar oksigen dalam darah tersebut kemudian dimasukkan nilai untuk suhu $37,5^{\circ} \mathrm{C}$, denyut jantung 75 dan konsumsi oksigen 0,5 ternyata hasilnya
$108,884 \%$ Hal ini perlu dikoreksi karena maksimal prosentase seharusnya $100 \%$,sehingga persamaan prediksi di atas tersebut perlu dikoreksi,yaitu dengan mengalikan dengan (100/108,884).

Hasil persamaan prediksi setelah dikalikan faktor koreksi menjadi :

$\hat{y}=\left(193,344-0,677 X_{1}-1,071 X_{2}+12,955 X_{3}\right)\left(\frac{100}{108,884}\right)$

Dengan adanya persamaan prediksi baru tersebut, maka dapat dibuat klasifikasi baru untuk kategori pekerjaan fisik sebagai berikut : Hasil persamaan Prediksi Kadar Oksigen Dalam Darah kategori pekerjaan ringan (denyut jantung 75 , suhu 37,5 dan konsumsi $\mathrm{O}_{2}$ 0,5) :

$$
\begin{aligned}
\hat{y}= & \left(193,344-0,677 X_{1}-1,071 X_{2}+12,955 X_{3}\right)\left(\frac{100}{108,884}\right) \\
= & (193,344-0,677(75)-1,072(37,5) \\
& +12,955(0,5)) *(100 / 108.884) \\
= & 100
\end{aligned}
$$

Untuk lebih lengkapnya dapat dilihat pada Tabel 9.

Tabel 9. Rekapitulasi Hasil Perhitungan Persamaan Prediksi

\begin{tabular}{|l|c|c|c|c|c|}
\hline $\begin{array}{c}\text { Kriteria Beban } \\
\text { Kerja }\end{array}$ & $\mathrm{VO}_{2}(\boldsymbol{L} / \mathbf{m i n})$ & $\begin{array}{c}\text { Ventilasi } \\
\text { Paru }(I / \text { min })\end{array}$ & $\begin{array}{c}\text { Suhu Rektal } \\
\left({ }^{\circ} \boldsymbol{C}\right)\end{array}$ & $\begin{array}{c}\text { Denyut } \\
\text { Jantung } \\
(\text { denyut/min) }\end{array}$ & $\begin{array}{c}\text { Kadar O2 } \\
\text { dIm Darah } \\
(\%) * *\end{array}$ \\
\hline Ringan & $0.5-1.0$ & $11-20$ & 37.5 & $75-100$ & $89,91-100$ \\
\hline Sedang & $1.0-1.5$ & $20-30$ & $37.5-38$ & $100-125$ & $79.83-89,91$ \\
\hline Berat & $1.5-2.0$ & $31-43$ & $38-38.5$ & $125-150$ & $69,74-79.83$ \\
\hline Sangat Berat & $2.0-2.5$ & $43-56$ & $38.5-39$ & $150-175$ & $59,65-69,74$ \\
\hline Ekstrem Berat & $2.5-4.0$ & $60-100$ & $>39$ & $>175$ & $\leq 59,65$ \\
\hline
\end{tabular}


Penentuan durasi istriahat

Perhitungan HRR

$\% H R R=85,46 \%$

Perhitungan CVL atau dengan perhitungan

nadi pemulihan.

Konsumsi energi

$E=1.80411-0.0229038(126.06)+4.71733$

x 10-4 (126.06)2

$1.80411-2.8872+7.4963=6.41321 \mathrm{Kkal} / \mathrm{min}$

Total metabolisme $=60$ energy $\mathrm{x}$ ox uptk

$=60(6.41321) \times 83.71$

$=32210.9 \mathrm{Kkal} / \mathrm{h}$

Tabel 10. Data Untuk Perhitungan Waktu Istirahat

\begin{tabular}{|c|c|c|}
\hline No & Keterangan & Hasil \\
\hline 1 & Denyut nadi/jantung & 126.06 denyut $/$ menit \\
\hline 2 & Konsumsi oksigen & $83.71 \mathrm{~L} / \mathrm{min}$ \\
\hline 3 & Energi & $6.41321 \mathrm{Kkal} / \mathrm{min}$ \\
\hline 4 & Total metabolisme & $32210.9 \mathrm{Kkal} / \mathrm{h}$ \\
\hline
\end{tabular}

Perhitungan waktu istirahat

$X=126.06$ denyut $/$ menit (kerja)

$E t=1.80411-0.0229038(126.06)+4.71733$

$$
\times 10^{-4}(126.06)^{2}
$$

$1.80411-2.8872+7.4963=6.41321 \mathrm{Kkal} / \mathrm{min}$

$\mathrm{X}=85.46$ denyut $/$ menit (istirahat)

$\mathrm{Ei}=1.80411-0.0229038(85.46)+4.71733 \mathrm{x}$

$$
10^{-4}(85.46)^{2}
$$

$=3.2921 \mathrm{Kkal} / \mathrm{min}$

$\mathrm{K}=\mathrm{Et}-\mathrm{Ei}$

$=6.41321-3.2921=3.12111 \mathrm{Kkal} / \mathrm{min}$
Karena nilai $\mathrm{K}=3.12111 \mathrm{Kkal} / \mathrm{min}<\mathrm{S}$ yaitu energi yang dikeluarkan selama bekerja kurang dari nilai standar energi yang dikeluarkan $($ pria $=5 \mathrm{kkal} /$ menit wanita $=4$ $\mathrm{kkal} / \mathrm{mnt}$ ) maka $\mathrm{Rt}=0$ artinya waktu istirahat untuk saat ini sudah cukup memadai, sehingga tidak dibutuhkan penambahan waktu istirahat.

Keterangan menggunakan persamaan Murrel : $\mathrm{Rt}=0$ untuk $\mathrm{K}<\mathrm{S}$

$$
\mathrm{Rt}=\frac{\frac{K}{S 1 X t(k . s) / \cdot b m}}{2} \quad \text { Untuk } \mathrm{S}<\mathrm{K}<2 \mathrm{~S}
$$

$\mathrm{R}=\frac{T(K \cdot S)}{K \cdot B M} \times 1,11$ Untuk $\mathrm{K}>2 \mathrm{~S}$

\section{Dimana :}

$\mathrm{Rt}=$ Waktu istirahat

$\mathrm{K}=$ Energi yang dikeluarkan selama bekerja

$\mathrm{S}=$ Standar energi yang dikeluarkan

(pria $=5 \mathrm{kkal} /$ menit dan wanita $=4 \mathrm{kkal} /$ menit)

$\mathrm{BM}=$ Metabolisme basal $($ pria $=1,7$

$\mathrm{kkal} /$ menit dan wanita $=1,4 \mathrm{kkal} /$ menit)

$\mathrm{T}$ = lamanya bekerja (menit)

\section{KESIMPULAN}

Dari hasil pembahasan yang sudah dijelaskan diatas, dapat diambil kesimpulan sebagai berikut :

1. Persamaan prediksi kadar oksigen dalam darah didapatkan persamaan sebagai berikut : $\hat{y}=\left(193,344-0,677 X_{1}-1,071 X_{2}+12,955 X_{3}\right)\left(\frac{100}{108,884}\right)$

2. Prediksi kadar oksigen dalam darah menghasilkan kategori baru untuk 
pengelompokkan kerja fisik, yaitu: kategori kerja ringan adalah 89,91\%-100\%; kategori kerja sedang 79,83\%- 89,91\%;kategori kerja berat 69,74\%-79,83\%;kategori kerja sangat berat 59,65\%-69,74\% dan kategori kerja ekstrim berat kadar oksigen dalam darahnya kurang dari 59,65\%.

3. Hasil dari nilai $\mathrm{K}=3.12111 \mathrm{Kkal} / \mathrm{min}<\mathrm{S}$ yaitu energi yang dikeluarkan selama bekerja kurang dari nilai standar energi yang dikeluarkan $($ pria $=5 \mathrm{kkal} /$ menit wanita $=4$ $\mathrm{kkal} / \mathrm{mnt}$ ) maka $\mathrm{Rt}=0$ artinya waktu istirahat untuk saat ini sudah cukup memadai, sehingga tidak dibutuhkan penambahan waktu istirahat

\section{UCAPAN TERIMA KASIH}

Penulis mengucapkan terima kasih kepada LPPM Unjani selaku pemberi dana pada penelitian ini, yaitu dalam hibah internal Universitas Jenderal Achmad Yani.

\section{DAFTAR PUSTAKA}

[1] Al Faritsy, A. Z., \& Nugroho, Y. A. (2017). Pengukuran Lingkungan Kerja Fisik dan Operator Untuk Menentukan Waktu Istirahat Kerja . 108-114.

[2] Salsia, K., Safitri, D. M., \& Anggraini, R. D. (2018). Intervensi Ergnomi Untuk Menurunkan Beban Kerja Pada
Operator Lantai Produksi Bisnis Unit South Copper ROD. 34-42.

[3] Wignjosoebroto, S. (2003). Ergonomi Studi Gerak dan Waktu. Surabaya: Guna Widya

[4] Soeleman, A., 2009. Kapasitas aerobik maksimum dan persamaan prediksi konsumsi oksigen pada perempuan pekerja industri. Unpublish Tesis Magister. Teknik dan Manajemen Industri, Institut Teknologi Bandung, ITB

[5] Kepmenakertrankop No: Per01/MEN/1978

[6] Nurmianto, E. (2004). Ergonomi Konsep Dasar dan Aplikasinya. Surabaya: Guna Widya.

[7] Mutia, M. (2014). Pengukuran Beban Kerja Fisiologis Dan Psikologis Pada Operator Pemetikan Teh. Jurnal Optimasi Sistem Industri, Vol. 13 No. 1,, 503-517.

[8] Silalahi, R. e. (2018). Beban Kerja Fisik Pekerja Pengolah Emping Jagung. Jurnal Teknologi dan Manajemen Agroindustri Volume 7 Nomor 1, 12-22.

[9] Benedikta, e. a. (2016). Analisa Beban Kerja dan Pengembangan Persamaan Prediksi Konsumsi Oksigen Pada Mahasiswa Pekerja Industri. 
Infomatek Volume 22 Nomor 2 Desember $2020: 89-100$

[10] Tarwaka. (2010). Ergonomi Industri. Harapan Press.
[11] Grandjean, E. (2000). Fitting The Task To The Human. Philadelphia: A Textbook of Occupational Ergonomics. 